\title{
The Contribution of Choreographers toward the Development of Minangkabau Dance
}

\author{
Fuji Astuti \\ Sendratasik Education Department \\ Faculty of Languages and Arts \\ Universitas Negeri Padang \\ fujiastutiep@yahoo.co.id
}

\begin{abstract}
It can be said Minangkabau dance at this time is growing rapidly seen from many dances performed and produced by choreographers and students from dance department. The dance activists, especially the Minangkabau choreographers, have also performed their dance masterpieces in various media as a means of cultural communication between countries. However, the dances presented tend to rely on the aspect of creative technical proficiency rather than critical appreciative skills. This is happened because of the desire to meet market tastes that encourage choreographers vying to pursue their popularity. It seems that the development of choreography from the past until now have different goals. The first dance is a manifestation of revealed community, but it is now more individual. Such tendency is dominantly reflected in students dance works, especially in the Sendratasik Education Department. Their dance works tends to use kinesthetic idioms that are not capable of being a symbolic system in expressing the idea to be proposed. This means that if the dance is placed at the level of ideological theoretical level which the dance as a cultural work that is not just the composition of the movement, but includes the manifestation of expression of human symbolic feelings, the dance seems not able to show as a cultural identity. Thus two unique skills, namely creative technical proficiency and the critical appreciative skills are the skills which are needed by choreographers. If a choreographer is solely based on procedural technical proficiency, then s/he is a seller whose works is a kind of industrial thing that can be multiplied based on his or her desire. The dance thus undergoes to the degradation into the product made by the technical-procedural. For that, both the choreographers and students from dance department should prioritize the values of local wisdom as a foundation in the work of dance that was created, so it can be a characteristics of their works. And, those are able to reflect the cultural identity too.
\end{abstract}

Keywords - choreographer, dance, local wisdom

\section{INTRODUCTION}

As explained by the previous researchers, Minangkabau people have a wealth of cultural art, such as dance, music, and randai that grow and develop in the community. In Minangkabau, art is controlled in each area (Nagari) and it becomes the pride of that area. So, the growth of art in each area can be different from the other areas. Besides, the performance of art in each area reflects the characteristics of that area so that the performance of arts can be felt and expressed.

Indrayuda said that through the performance of Piriang dance, it can show the identity of the Minangkabau community. Furthermore, through the dance, we can see the characteristics and culture of Minangkabau community. Thus it can be said that the arts activities such as dance and music that exist in the community are inherent with the social life.

However, it is difficult at this time to find out the kind of dance works in which the values and norms are displayed as a common expression in the Minangkabau community. The form of dance presented is more about the individual expression. It means that only few of dance works that carry out the the expression of Minangkabau community. This phenomenon is not only happened in social community in minangkabau but also in some institutions of formal education. So, the institutions have to be able to keep the characteristics of Minangkabau works as the reflection of the identity of Minangkabau culture

It is realized that a change in society cannot be avoided, because of the heterogeneous people in Minangkabau community. Moreover, it is so vulnerable to be influenced by the other cultures, such as s balanse madan dance, melalyu dance, baronsai art and others. So, the change should not o through the basic of the characteristics of Minangkabau community because it can make the characteristics of Minangkabau society become lost.

It is recognized at this moment that the growth of a number of Minangkabau choreographers, especially female choreographers bring the positive and negative change in Minangkabau society. The positive change is that the choreographers' works are grown based on their own creativity. However, that change brings the negative effect. The negative effect is that many of dance works which are created by them are adopted from the western cultures which are based on the individual expression. Furthermore, they create the works to reach the popularity among others, as individual needs, not for the social community interest.

If we observe the changes occurring in Minangkabau society in the past, women are not given the opportunity to participate in artistic activities, either as choreographers or as dancers, because it is considered as a taboo if women exhibit themselves around society. At that time the concept of "shame" and "aurat" in the custom and religion in Minangkabau cannot be negotiable. But after the period of time, the changes are occurred. The Minangkabau women fight to be involved in the public, in this case is in 
the arts activities. The presence of women in the arts/dance activities is evident in the grips of Huriah Adam. Although at first the Huriah Adam was received the cultural challenges, but in his work as a leading choreographer with a number of dance works he created, can still be perceived as joint ownership, even though the work of the dance is laid out personally. The creations of dance originated from pencak silat are arranged so that the work is acceptable and can still be remembered and felt today. It shows that the figure of Adam Huriah still consider the essence of local wisdom values underlying in his dance works, so that the work of dance can still show the cultural identity that can be digested, felt both among local community and society outside Minangkabau. Besides, Gusmiati suaid, in his expertise embodied in the works of dance is also found the challenging way, because it is considered the work of his dance rooted from the martial arts which is considered too hard and not suitable for women. In the other hand, Syofyani with a number of his dance works shows a dance movement that combines martial arts movements with the motion of Malay, so that the tenderness of dance movement presented is considered very suitable for Minangkabau women (Astuti, 2004, 133-158). It shows that a change occurred in the community is responded by the adat stakeholders, alim ulama and cadiak pandai who are on tigo tungku sajarangan. It means that once a change occurs, people in community take part, not just silence, as it happens. Similar with this moment today, the change in the arts activities overlaps and becomes a tight discussion among the Minangabau community.

For example, the art activities especially the dance developed today tends to leave the values of local wisdom. For example, masculine dance movements are commonly played by women with kicking and flipping with both legs wide open. The dress that women wear is tight and transparent and it is not appropriate with the contents of the dance displayed. Modern techniques with contemporary sculptures make it difficult for choreographers to consider the values and norms. It should be embodied in the created dance work, so that the dance can reflect the ideal Minangkabau female figures, who always consider the ethical, aesthetics, and the logic that keep in every action.

The Minangkabau women's philosophy which is described as siganjua lalai dari pado maju suruik nan labih, samuik tapijak indak mati is just a selogan and not in real life, especially in the work of dance that is displayed. Of course this phenomenon occurs by the shallow understanding and concern of a choreographer to select, select the shapes and patterns poured through the motion used. Apparently the Minangkabau says that "sakali aie gadang, sakali tapian barubah"means that the Minangkabau people realize that the transition process of change in social life of society is unlikely to be avoided. The question is whether the changes that occur in the works of dance is regarded as a common thing? How should the attitude of choreographers as a "voice" of expression which is as representatives of the society can be appreciated by the audience as a reflection of attitude and behavior of Minangkabau society, especially for female practitioners in the art.

\section{DISCUSSION}

Dance can be used as one medium expression through the medium of motion. Whether it is delivered or not depends on the ability of dancers in expressing the message communicatively. It is highly demanded the ability of dancers in understanding the meaning and content contained in the dance presented. Besides, the ability of a choreographer in arranging the dance is very decisive to the direction and goal of dance that is to be achieved. While the dancer is as the agent that brings the choreographer's idea visualized through the media of motion. Therefore it cannot be separated between the choreographer and dancers and the role of choreographer is very important as someone who brings the color and identity of dance works that they made.

The creativity of a choreographer result the quality of their works that they create. It means dance and creativity cannot be separated, because creativity is the heart of dance. So, the choreographers should cover the elements of the dance in order to make the dance is understood by the others. There are two unique abilities that should be taken into account by the choreographers. Those are the ability of creativity technique and the ability of appreciative-critique. If the choreographers only focus on the ability of procedural technique, their works are just for the world of industry. Such tendency is dominantly reflected in the dance works both made by creators of dance or the institution. In Sendratasik Department Faculty of Languages and Arts Universitas Negeri Padang, the dance works cannot be as a symbolic in expressing ideas. So, the choreographers have to have the ability of creative technique and appreciative-critique that can make their works good.

Academically, making the dance works with the ability of creative technique has to be owned by the choreographers. However, in the performance, the creators generally cannot explain why the idiom of movement is expressed in their motion. The understanding of movement in cultural aspect means a level of understanding that might make someone as a choreographer become an author of their works (Finding of Astuti, 2005).

In line with Humphrey (1983: 18), the reason why many choreographers fail is because of the insensitivity of someone toward the others problems. So, choreography is defined as a process of realization that is communicated symbolically through the movement. The choreographer has an important role as someone who has high responsibility in processing the ideas through the movement media. Besides, the process of making content in dance is also important. The content of dance can be seen from how someone processes the ideas. Ellfedt (1967: 15) also said that the main point of dance is seen from the content. The content is also defined as something that the choreographer wants to express.

Murgiyanto (1983: 30-31) argued that a dance is defined as a form that is composed well organization. So, to make the dance works is understood by the audience, the ideas of dance should be grown from the choreographers' experience. He also said that: 
We often place the form as the part of dance that we only observed. We have never gazed that the principle of dance is based on the activity of people in daily life (Murgianto 1983: 31)

Bsed on the definition above, the form of dance can be understood from the two aspects. First, form can be understood as he invisible form, that means the inner form; the idea is based on the elements of spiritual. Second, the outer form is defined as a result of arranging the motoric elements that can be seen. So, when we observe and talk about dance, the content and the form cannot be separated.

\section{Dance as a Cultural Identity}

In principle, dance can be viewed from two aspects, namely dance as a product and dance as a process. As a product, dance can be observed in the form of a dance work that has an aesthetic value. While the content of the aesthetic values can be seen through the elements of dance that is constructed into a unified form of dance form that is harmoniously interwoven. While as a process, dance can be observed from the human behavior to see the reflection of ideas, thoughts, and feelings of individual souls as well as collective as a cultural expression that is imagined through the media of motion. Murgianto (1986: 121) states actually a dance composition can be done by utilizing the patterns of motion of tradition that have been existed before something new is developed. On the other hand, the dance can be based on the environtment and people's life. The views of Doris Humprey and Sal Murgianto require that choreographers have to understand deeply about the source that is used as the foundation of their works so that the created works of dance can be properly accounted.

The study of dance is ultimately used to know and understand the cultural identity of community. Cultural identity can be interpreted through the uniqueness, civilization, and personality imposed in the local environment. The uniqueness can be described through the cultural products such as through dance performances. While the personality and civilization of the local culture can be observed through valuable cultural values that are expressed and visualized through the medium of dance movement. The Dance performances can reflect the life of the local community in accordance with the values and cultural patterns in which the art of dance is growing and developing. In other words, by performing, it can be used to know the values and views of life of the local community. In line with Soedarsono in Gere (1992: 48) that said that when someone observes and learns Javanese dance for example, it means that person also learns ethics, courtesy, moral, even ancestral legends that grow in local culture as the embodiment of cultural identity in the community.

\section{CONCLUSION AND RECOMMENDATION}

Dance as one of the cultural products that can be as a mirror of attitude and behavior of culture. However, the role of choreographers is very importance in making dance works. It means that the form of direction and goal that is to be achieved depends on the idea of a choreographer's idea that is immersed in a concept.

To make a dance presents collective values as the mutual expressions and as a cultural product, a choreographer must be selective in choosing the source on which the creation of a dance is based. In this case the values of local wisdom can be used as the foundation underlying a work, so the dance that is created reflects the cultural identity of each community.

\section{References}

Astuti, F. (2004). Perempuan Dalam Seni Pertunjukan Minangkabau; Suatu Tinjauan Gender. Yogyakarta. Kalika.

Astuti, F. (2005), Tinjauan Karakteristik Karya Koreografi Mahasiswa Pendidikan Sendratasik FBSS Universitas Negeri Padang. Laporan Penelitian Direktorat Jenderal Pendidikan Tinggi Depertemen Pendidikan Nasional

Ellfedt, L. (1967). Pedoman Dasar Menata Tari. Terj. Salmurgianto. Jakarta: Lembaga Pendidikan Kesenian Jakarta.

Gere, D. (1992). Looking Out: Perspektives On Dance and Criticism in a Multikultural World. New Yokr: Shcicnner Books.

Humphrey, D \& Murgianto, T, S. (1983). Seni Menata Tari. Jakarta. Dewan Kesenian.

Murgianto, S. (1983). Koreografi, Pengetahuan Dasar Komposisi Tari. Depertemen Pendidikan Dan Kebudayaan.

Putri, D. dan Mitarlis. (2015). Pengembangan Lembar Kerja Siswa Berbasis Mind Mapping pada Materi Laju Reaksi 6untuk Melatih Keterampilan Berpikir Siswa Kelas XI SMA. UNESA Journal of Chemical Education 4(2) 340-348.

Riduwan. (2013). Skala Pengukuran Variabel-Variabel Penelitian. Bandung: Alfabeta

Trianto. (2009). Mendesain Model Pembelajaran Inovatif Progresif. Jakarta: Kencana.

Wisdiarman (2007) Pengaruh Strategi Pembelajaran Discovery dan Motivasi Belajar Terhadap Hasil Belajar Menggambar Bentuk. Jurnal Forum Pendidikan, 3(2): 111-118

Wisdiarman dan Zubaidah. (2014). Pembelajaran Berbasis Kurikulum 2013. Padang: Seni Rupa FBS UNP Padang 